\title{
Political Economy of the Muslim Middle Class in Southeast Asia: Religious Expression Trajectories in Indonesia, Malaysia, and Thailand
}

\author{
Abdur Rozaki ${ }^{1}$ \\ Sunan Kalijaga State Islamic University, Indonesia \\ Bayu Mitra A. Kusuma² \\ Sunan Kalijaga State Islamic University, Indonesia
}

Abd. Aziz Faiz ${ }^{3}$
Sunan Kalijaga State Islamic University, Indonesia

\begin{abstract}
The growth of Muslim middle class in the three Southeast Asian countries namely Indonesia, Malaysia and Thailand are heavily influenced by each state's political development policy as well as the growing phenomenon of the Muslim market as part of the global market dynamics. This paper aims to describe the phenomenon of state and society relations in regards to policies that influence the growth of the Muslim middle class and how the market contributes to their expansion. The research shows that Muslim middle class in Indonesia is a result of the ever-crisscrossing force between state-driven promarket policies, market-driven mechanisms, and the development of information technology that creates the demands of modern lifestyles. In terms of the Malaysian context, the Muslim middle-class formation is closely linked to a state driven policy in the form of ethnicity-based policy: an affirmative policy to strengthen the Malays, which is identical with Islam. While for the case of Muslim middle class in Thailand, the formation is largely determined by the central government's political policy. The Thai government uses different political approaches, which varies depending on the level of the Muslim community's compromise in each region. In the end, the differences in the process of Muslim middle-class formation in these countries shaped their Muslim communities' religious expressions both economically and politically in the public sphere.
\end{abstract}

Keywords: Political Economy, Muslim Middle Class, Religious Expression, Southeast Asia

\section{Introduction}

In the past decade Islam has been perceived in contradictory twosided religious expressions, namely intolerant or uncivilized and tolerant or moderate (Schønemann, 2013).
These differing religious expressions are highly correlated to structural and social class backgrounds. The study of the middle class has always been an attractive issue among academics and social activists, which is primarily

\footnotetext{
${ }^{1}$ Corresponding e-mail: rozaki75@gmail.com

${ }^{2}$ Corresponding e-mail: bayu.kusuma@uin-suka.ac.id

${ }^{3}$ Corresponding e-mail: faizazizofficial@gmail.com
} 
attributed to the fact that as a middle group, they come up with a strategic role and function of connectivity and other intermediary in diverse political, economic and cultural arenas (Bagguley, 1992). In this context, the middle class plays a significant role as the driving force of social transformation owing to its ability to represent the interests of the elite class, while influencing the interests of the grass-root.

With the benefit of hindsight, it is apparent that the last decade has been witnessing the fascinating dynamics of the middle class, principally the Muslim middle class in three Southeast Asian countries, namely Indonesia, Malaysia and Thailand, especially in relations to the changing political regime and economic growth in the region. Each country in the Southeast Asian region has its own unique characteristics of Muslim middle-class society with its own social conditions, which result in different religious expressions in the public sphere. For instance, in areas where Islam is the less dominant group there are more widely varied behaviors, perspectives, and communal cultural practices than in places where Islam is the mainstream group (Hisyam, 2006). These widely varied Islamic religious expressions are portrayed demonstratively in the public sphere.

The government plays a significant role in the encouragement of development policies and opening market access, which led to the growth of the Muslim middle class in various Southeast Asian countries. This paper focuses on the dynamics of the Muslim middle class in Indonesia, Malaysia and Thailand through the perspective of the government's role and its relations to the life of the civil society. This paper analyses how the Muslim community adapt to government-led social changes and how they negotiate and resist these changes. Additionally, this paper also addresses how the market reflects the ever-growing middle-class religious expression in the public sphere.

The formation of the Muslim middle class in Indonesia is formed through the ever-crisscrossing force between the state-driven pro-market policies, market-driven mechanisms, and the development of information technology that creates the demands of modern lifestyles. Meanwhile, in terms of the Malaysian context, the process of Muslim middle-class formation is closely linked to the state driven policy in the form of ethnicity-based policy, an 
affirmative policy to strengthen the Malay ethnicity, which is identical with their Islamic identity (Neo, 2006).

For the case of the Muslim middle class in Thailand, the formation is largely determined by the Bangkok central government's political policy. Yet, in contrast to the Indonesian and Malaysian cases, which affect the state's Muslim population indiscriminately, the Thai government's policy targets particular Muslim sub-populations. As a result of the government's soft power approach, the Muslim middle class emerged in Nakhon Si Thammarat. In contrast, the central government's strong-arm security policy towards the Muslim population in the Pattani Province has limited and restricted the development of its Muslim middle class. The government's security approaches in Pattani has left its Muslim community with constraints in market access and business expansion.

The many social and political factors at play in the emergence of the Muslim middle class in the three Southeast Asian states result in a variation in religious expressions in the public sphere both politically and economically. In other words, the crisscrossing linkage between Islam and the middle-class society intertwining one to another is worth studying owing to the existence of the pattern of class-consciousness for access ownership, capital ownership, and power ownership to construct the social trajectory (Wright, 1989).

This paper explores the social phenomenon that signifies the emergence of the Muslim middle class in Indonesia, Malaysia and Thailand and how is this emergence expressed in the public sphere. These questions are certainly contextualized in accordance to different political contexts of each country, thus generating a diverse response in the use of political access and other economic opportunities.

Indonesia: The Muslim Revival in Post New Order

It is hard to map out the formation of a Muslim middle-class society in Indonesia without taking into account the political upheaval and capitalist patterns instilled in the Indonesian economy. Such context can be observed at least since the Dutch colonial times, when the Muslim middle-class traders established Sarekat Dagang Islam (The Islamic Trade Union, SDI) in the early 1900s (Fealy \& White, 2008). SDI, which later turned into the Sarekat Islam (The Islamic Union, SI) in 1921, is a socio- 
political organization founded as a struggle against the Dutch colonialism that privileged trade for the Europeans, Wong Tjina or the Chinese, and the local aristocracy (Jati, 2017).

SI seeks to muster the Islamic forces to take part and fight for more just economy through class approach and the spirit of Islamist movement. The birth of SDI or SI marked a new chapter for Islam as it shifted from a cultural movement into a political movement. The downfall of SI subsequently led to the birth of other Islamic social movements, such as Muhammadiyah, Nahdhatul Ulama (NU), Persatuan Tarbiyah Islamiyah (Perti), Persatuan Islam (Persis) and others (Romli, 2004). The post-SI Islamic organizations continue to develop a pattern of commercial networks, distanced from the class approach by seeding a softer political-religious approach than the previous SI. It is apparent that the pattern of the Islamic movement they developed is deeply rooted from nationalism, which turns out to be the ideal spirit of the movement to go against colonialism.

Following the Indonesian independence in 1945, President Soekarno introduced the Benteng (fortress) Economic Program policy in 1950. This policy provided the entrepreneurs involved in the program with various privileges ranging from import licenses, venture capital, to business training (Wiharja \& Negara, 2015). This policy was also set up as a strategy to restrict the Chinese businessmen who began to dominate the market. However, this strategy was deemed to be a complete failure because many of the recipients of the bank capitals did not make use of the loan to finance businesses or productive activities, instead they preferred to used it for consumption rather than investment (Wiharja \& Negara, 2015)

Soekarno finally decided to end the Benteng Economic Program and replaced it with a series of economic nationalistic policies in 1957 . The new program was designated with three main strategies to eliminate foreign capitalists by nationalizing foreign companies, establishing state owned enterprises (SOEs) to manage nationalized companies, and replacing imports with local production for a selfsufficient economy. Yet, similar to the doomed fate of the Benteng program, these policies also faltered. Many of the newly established the SOEs faced inefficiencies and mismanagement due 
to the government's preference towards putting people who were of close proximity to the military and political parties to manage the SOEs (Robison, 2012).

After the 1965 crisis, Soekarno's government was overthrown by the Soeharto-led military. The change of ruling power consequently led to the change of the economic direction policy. As a president Soeharto made a stark difference to Soekarno's nationalist economic policies. He opened the doors for foreign investment, claiming that Indonesia shall join the network of international capitalism (Masitho, 2013). This new policy fostered the growth of several groups of capitalist classes from the military, bureaucrats, technocrats, politicians, relatives and key business partners of the regime such as the Indonesians of Chinese descent. Soeharto's New Order regime built up the middle class as part of a program to develop a new bourgeoisie to strengthen the country's economic development process. In a sense, the Indonesian middle class during the New Order era was a class of state dependence (Robison \& Goodman, 2013).

During Soeharto's New Order period, the indigenous capitalist class was classified into three different groups. The first group is comprised of entrepreneurs who were raised by the Soekarno government's nationalist economic policy. The second group embraces the bureaucrat entrepreneurs who formed enterprise with family-dominated private groups, such as Soeharto's family. The third group is the newly emerging capitalist groups raised by political and bureaucratic protection, such as the Kosgoro Group and the Sahid Group. Additionally, the New Order regime also established business networks with the Indonesian Chinese capitalist class. Among the Chinese business corporations known to be close to the political bureaucrats and Soeharto were the Astra Group run by William Soerjadjaya and the Salim Group of Liem Sioe Liong (Borsuk \& Chng, 2016).

The New Order went on with endless endeavors to set up the middle class in the early 1990s by working hand in hand with Islamic groups through the establishment of the Association of Indonesian Muslim Intellectuals (ICMI). The association was designated for intellectuals and Muslim bureaucrats to allow them to make contribution towards ideas for development of the country. The establishment of this new institution is inseparable from the role of the Muslim 
middle-class groups who were actively involved in approaching the government for decision-making. Therefore, the birth of ICMI could be seen as a momentum of unity between state interests and that of the Islamic groups.

It is in the contention of Robert Hefner (1995) that the relationship between Soeharto and ICMI is a mutually beneficial relationship, since Soeharto was in need of bureaucracy reinforcement whilst Muslims were in need of political positions in the government. The government's accommodative attitude towards the Muslims was attributed to social change occurring since the 1980s, where the Muslim middle class that were mainly constituted of intellectuals and entrepreneurs began to come to the fore. The good relationship between the New Order government and the Muslims was proven as Soeharto appointed some Muslim intellectuals to occupy some prominent positions in the government. The mobilization of the Muslim middle class into the government then gave rise to the idiom of "bureaucratic santrinization" (Jurdi,

"The term "santri" refers to Islamic students. Thus, the terms "bureaucratic santrinization" refers to how Islam has influenced the Indonesian government bureaucracy at that time.
2013). Aside of the accommodation of Islamist movement by the regime, Soeharto also began to express his Islamism by making a hajj pilgrimage in 1991. Additionally, Golkar-the currently ruling party-also initiated mosque construction program in various regions across Indonesia.

After the fall of Soeharto in 1998, the growth of the Muslim middle class in Indonesia found a new catalyst. Unlike the Muslim middle class of the New Order era, which flourished under state driven forces, the Muslim middle class during the Reformation era also proliferated through market driven mechanism. This period is signified by the growth of the Muslim market phenomenon. Both the state driven and market driven forces jointly propelled the growth of the Muslim middle class in Indonesia at this time. The state driven factor is evident in the fact that the old entrepreneurs of the New Order era remained along with the newly burgeoning entrepreneurs. These new entrepreneurs made use of the political opening upon the fall of Soeharto's authoritarian regime also opened up opportunities for new actors to enter the middle class.

Soeharto's fall has introduced an electoral democracy, which has allowed 
new actors to occupy political positions in the government. These new political actors opened up access to capital for new groups of people, which effectively allowed them to enter the middle class. Moreover, the decentralization of power and regional autonomy in Indonesia marks a compelling political contestation between more than handfuls of entrepreneurs who engaged themselves in politics. An example from Yogyakarta is Herry Zudianto, a businessman who is closely related to the Muhammadiyah. Zudianto joined the National Mandate Party (PAN) in 2001 and was elected as the Mayor of Yogyakarta for two periods through electoral democracy. In a similar vein, Hafidh Asrom, a businessman who was greatly supported by the Nahdlatul Ulama and had an established position within the organizational structure of the organization, also decided to enter politics by running for the election of the Sleman Regency in Yogyakarta in 2000 and 2005. Despite his defeat in two elections, he ran for the position of a senator in the Indonesian House of Representatives and managed to secure the position for two periods in 2004 and 2009. In terms of business, both entrepreneurs run their own successful business groups. Initially starting with garment stores, Herry Zudianto has expanded into the Muslim lines of fashion and education. Likewise, Hafidh Asrom started with a furniture company, but later on he is well known nationwide for his private Islamic educational brand, the Al-Azhar School.

Herry Zudianto and Hafidh Asrom provide an example of a social phenomenon in line with the finding of a study by Ali and Purwandi (2017) about the Muslim middle class in the Reformation era. According to their Survey, $59.7 \%$ of the Muslim middle class is closely related to Nahdlatul Ulama (NU) mass organization, followed by $11.0 \%$ who admitted their relations to Muhammadiyah. Meanwhile, the remaining $26 \%$ respondents claimed to have no proximity to any Islamic organizations (Ali \& Purwandi, 2017). The Muslim middle class' closeness to $\mathrm{NU}$ is primarily underpinned by several factors, including family affiliation with the Nahdliyyin, a common understanding of Islamic religion with that of NU, and an interest in NU's moderate teachings.

Some prominent figures that made the best use of the market driven phenomenon and the formation of 
the Muslim middle class, such as Yusuf Mansur, Pamella Sunardi and Jody Brotosuseno provide an interesting case to study. These people were born with self-reliant characteristics and stand on their own feet of initiative to grow given the fact that they have little access to take advantage of government programs in economic development. Their survival skills and endurance to develop business networks generally lie in their accurate foresight in reading market trends.

Yusuf Mansur's proficiency in foreseeing market demand for easy access to sharia-based finance services drove him to form PayTren Payment Gateway and PayTren Asset Management, which are shariacompliant web-based payment service and asset management company. In his view, there is an attractive prospect for sharia compliant financial business to thrive given the demand from the Muslim middle-class market. This is evidenced from the number of PayTren Payment application users who have amounted to 1.6 million with electricity transactions of 800,000 each month (Laucereno, 2017). In addition, other major transactions are the purchase of credits as well as train and plane tickets.
Another entrepreneur who harnessed the opportunities in the Muslim market is Nurhayati Subakat, a cosmetic entrepreneur who established Wardah, a halal cosmetic brand. Wardah's success is not contained in the local market, but it also sprawled the international market. Nurhayati has foreseen the promising market potentials of halal goods in Indonesia along with the increasing cosmetic consumption. Survey Results of Panel Service Nielsen Indonesia in 2013 (The Jakarta Post, 2013) shows that the use of cosmetics is mainly attributed to the fact that more people realize the importance of retaining the look of beauty despite the rise in prices of cosmetic products. The make-up awareness trend is not only flourishing in urban areas, but also thriving in the remote areas in Indonesia.

The success of Yusuf Mansur's sharia compliant financial services and Nurhayati Subakat's halal cosmetics shows how the Indonesian Muslim middle class's consumption pattern reflects their faith and economic prosperity. As Carla Jones posits, religious goods can be used as a signifier of class mobility (2007). Aside of the financial services and the beauty 
industry Islamic influence has also found its way in other sectors as reflected in the proliferation of Islamic education, Islamic fashion, Islamic entertainment, and halal tourism (Fealy, 2008).

Malaysia: Affirmative Policy as Malay Muslim's Privilege

From the colonial times until the independence in 1957, the population in Malaysia has always been classified based on ethnicity (Nagaraj et al., 2015). The predominant ethnic group is Malay, which is identically correlated with the indigenous and Islamic identity. This ethnic population composition is also seen in the structure of work, for instance the distribution of income in Malaysia can be delineated upon ethnicity (Guan, 2002). The economic structure and composition of these ethnically based populations indicates the economically backward Malay in comparison to the Malaysians of Chinese descent. This situation led to social jealousy and tension, which eventually burst into anger and riots between the Malay and Malay Chinese on May 31, 1969. The ethnic unrest in 1969 was the culmination of the Malay dissatisfaction for experiencing longterm political discontent due to socio- economic disparities that led to social segregation in the society. In order to avoid such riots from recurring, the Malaysian government tried to improve social harmony and promote national unity by enacting ethnicity based economic policies, which prioritizes the Malays (Afzal, 2018). The New Economic Policy (NEP) was eventually adopted in 1971 as a response to the problem. NEP delineates two things: reducing poverty by raising the level of people's income through job opportunity enlargement and accelerating the process of the Malaysian society restructuring in establishing an economic balance. The NEP became the basis for the orientation of the industrialization policy in Malaysia (Talib, 2000).

The Malaysian Federal Constitution stipulates that the bumiputra, which comprise of Malays and natives of Sabah and Sarawak, may obtain privileged access to public-sector jobs, enterprise licenses, rent opportunities, government contracts, scholarships and entry to public universities (Balasubramaniam, 2007). The bumiputra classification effectively excluded the ethnic Chinese, Indians and other nonindigenous peoples of Malaysia from these privileges. The classification, which 
favors the bumiputra, is reflected in the Malaysian government's NEP.

To encourage the participation of the Malays in the economy, in 1978 the government established the Bumiputra Investment Foundation, to strengthen bumiputra's capital ownership. Through the establishment of the Industrial Coordination Act, the state organizes the industry, while at the same time encouraging the bumiputras' involvement in the development of Malaysian industry. The same reason also applies for the establishment of the Outline Perspective Plan One where the state promotes equitable economic distribution, economic restructuring, employment distribution, and the ownership of internal aspects of corporate sectors for the Malays. As for the improvement of science and skills of the bumiputra, the government established the Rida Training Center and Mara College (now known as Universiti Technology MARA or UiTM).

The NEP policy which was designed for a span of 20 years does not only regulate the primary sector, but also seeks ways to reduce regional disparities between ethnicities and to raise the incomes, education and health care of the Malays (Hansen et al., 1990). Amongst other privileges provided to the Malays are the subsidy for the construction of simple homes for the low-income society of below RM 5,000 per month, scholarships for education at home and abroad, and the provision of 10 acres of land for Malays who migrate to new industrial areas, and the establishment of Bumiputra small business union.

The provision of the NEP as the first wave of the government's policy revolution had three impacts. Firstly, the government bureaucracy becomes predominantly controlled by the Malays. Secondly, the Malay professionals increasingly grew in various fields. Finally, the number of Malay owned enterprise also grew. The next step that that marked the second wave of policy revolution was the National Development Plans (NDP) in 1990s. This second wave of policy revolution is signified by the globalized market economy, government subsidy reduction, and the growing Muslim Malay middle class across all sectors. Instead of focusing on ethic-based policies like the first policy revolution wave, the NDP, focuses on statedependent affirmative policy toward privatization. This policy continued to apply until the 2020 policy plan, 
namely Malaysia's Multimedia Super Corridor and Vision 2020 (MSC). The NDP and MSC policies open up private market opportunities and slightly lessen bumiputra's privileges. The state's business policy vision is designed to make Malaysia an advanced industrial economy of large and medium-scale industries and to reform its citizens' way of life in the globalized world (Mohammad, 1991).

The projects within MSC included the development of Kuala Lumpur City Center (KLCC) luxury commercial tower, Kuala Lumpur International Airport (KLIA), and the national sports industry complex. The state also boosted palm oil plantations under the coordination of the Land and Development Authority. Additionally, the government also developed Putra Jaya to serve as a new administrative center and Cyber Jaya as a new center of commerce and technology.

Both the NDPand MSC facilitated the growth of the Malay intellectual middle class that increasingly spread in various professions, such as businessmen, engineers, managers, doctors, and other professional competencies. The success of the country's industrial policy and the increasingly high level of ethnic Malay education created an increasing urban flow from rural to urban areas annually (Thillainathan \& Cheong, 2016). The success of the state's industrial policy also improved the level of life of the Malays (Lall, 1995). In other words, it is possible to assume that the investment of the country, through scholarships and access to education quotas for the Malays in the first wave of policy revolution has spawned the explosion of professionals in various fields, whilst the government's development projects in the second wave of the policy revolution have further created the demand for these professionals.

Despite the Malay's social mobility, the Malaysian middle class is also said to suffer due to the country's economic policies in the second wave of policy revolution. For instance, various subsidies introduced in the first wave of policy revolution were limited to people in the lower social class. This change was deemed necessary to catch up with the market economy. Such condition has led the state-dependent Muslim middle class to suffer as they have to strive more independently without the state's support. Additionally, they are also faced with subsidy cuts amidst the everdemanding new middle-class lifestyle. 
The expression of the middle-class Malay Muslims in the public space provides no less interesting topical issue since their mobility is apparent from the rise of Islamic symbols in the public sphere. The Muslim middle class carries Islam with them as a class identity, signifying Malaysia's image as a country of a predominantly Muslim population. The religious expression as seen from Islamic life styles can be observed in three important ways: the existence of the state sharia policy, the emergence of the Muslim market, and Islamic philanthropy.

Firstly, the state's sharia policies have accommodated the growth of religious expression in the business sphere. In 1993 Bank Negara Malaysia (BNM), the central bank, allowed conventional banks to operate Islamic "windows" under the Interest-free Banking Scheme (Ariff, 2017). Initially, the three largest conventional banks in Malaysia, which were Bank Bumiputra Malaysia Berhad, Malayan Banking and United Malayan Banking Corporation were given license to operate Islamic windows. By the end of 1993, there were already 21 conventional banks with Islamic windows.

Secondly, Islamic religious expression may also be observed through the Muslim market mechanism. For instance, the Muslim middle class' preference to consume halal food and products may be observed across different sectors. For instance, the growth of salons and beauty products with halal label reflect this the Muslim middle class' consumption pattern. Some products such as Sendayu Tinggi, Atika Beauty, Nouvelles Visages, De 'face, Maintainability Anis's beauty, the Large Wave, Jelita Ayu, Biodex, World Herb, D'Navechee and Yusmira Cosmetics, are among the most sought after by the Muslim middle class in Malaysia (Yacoob \& Azmi, 2012). They also yearn for other Islamic products, such as Islamic teaching, Qur'anic reading classes, Islamic TV broadcasts, Islamic magazines, Islamic films, and hijabs with all of its accessories. The halalness of products and its consumption cultures becomes what Johan Fischer deem a part of the narrative of the awareness of Islam and the class inherent in the Muslims' everyday identity (2008).

When it comes to the desire to consume Islamic ideas, there are some popular Islamic preachers such as Ustadz Mohd Fadzillah Kamsah, a well-known preacher and motivator on television and the social media, or 
Ustadz Mohammad Kazim Elias, who is widely praised for his comical style. Additionally, the Muslim middle class in Malaysia also has the option to send their children to Islamic private schools or tahfidz (Quran memorization) schools. Some famous schools in this line are the Raudah Islamic School in Kajang, and Darul Huffaz International Tahfiz and Science Academy, which operates many branches across Malaysia.

The third observable religious expression in Malaysia is Islamic philanthropy. The religious expression in this context is primarily organized through surau-a worship place such as mosque-for example An-Nur Welfare Association or PKIAN (Hasan, 2000). The state also plays an important role in the philanthropic aspect for the middle class by imposing a monthly salary deduction for all employees for zakah charity by $2.5 \%$. The deduction termed as Skim Thohir was handed over to the Tax Collection Center (PPZ), which was inaugurated by the Regional Islamic Council (Majlis Agama Islam Wilayah Persekutuan). Malaysian Muslims generally prefer to distribute their zakah through these organizations rather than as individual donations. Some of the trusted organizations are the IKRAM Malaysia and the Malaysian Muslim Association (ISMA). Thus, the philanthropic aspect in Malaysia does not rely much on individual culture as the prime mover.

Thailand: Muslim is Not Only about Pattani

The existence of Islam in Thailand has mainly been represented by the Muslims Pattani, Yala, and Narathiwat provinces, which constantly suffer from marginalization. Nevertheless, seeing Islam in Thailand only through the three provinces would be too narrow to describe the full picture of Muslims in Thailand who are scattered and in various regions. The Thai Muslims are remarkably adaptable to cope with the demands of time, to compromise with global influences, and to cleverly establish new identities without giving up their original beliefs and identities. One of such provinces displaying such characteristics is Nakhon Si Thammarat, a province in the Southern part of Thailand.

According to the researchers' observation, in Nakhon Si Thammarat, the government provides its Muslim community with access to public facilities and treatment like citizens of 
other religions. In daily life, the local people deem Muslims as good and of "high ranked class" citizens, which consequently allows the Muslims a room to hold their activities normally. For instance, Muslims in Nakhon Si Thammarat are provided with access to both religious education in boarding schools and formal school education. This situation is in contrast to the Muslims in Pattani, which have a limited access to education that led to poor human resources quality in the region. The Thai government treats the Muslim community in Pattani-another province in the Southern part of Thailanddifferently from those in Nakhon Si Thammarat. In Pattani the police and military always cast a suspicious look at them and their daily activities were disrupted by the countless checkpoints that must be passed.

Historically southern Thailand is marred with an ongoing conflict. It originated in 1948 as an ethnic and religious separatist insurgency in the historical Malay Pattani Region in the three southernmost provinces of Thailand (Islam, 1998). To curb the insurgency the government attempted to legalize the military's presence in Pattani by enacting three laws, which are the Martial Act Law of 1914, the Emergency Decree of 2005, and the Domestic Security Act of 2008. Under those prevailing three laws, a soldier or police officer is in charge of supervising 100 civilians. With such a legal structure, the military is fully authorized to carry out actions such as unauthorized arrest, shooting people deemed suspicious or dangerous, and to have legal immunity in doing so.

In terms of local politics, Muslims in Nakhon Si Thammarat are given relatively wide access through three representatives in provincial councils, which are selected through electoral democracy. This is in line with the Decentralization Act of 1997, which provides a constitutional mandate in local elections. Electoral democracy provides an opportunity for Muslims to become public figures in Nakhon Si Thammarat. This is attributed to the modern political transformation of Thailand, which began to develop in 1932, which limited the power of the Thai monarchy in the name of democracy. The Thai democracy gives rise to political access not only to Muslims at the local level, but also at a national and even an international level. For instance, Surin Pitsuwan whose 
political career skyrocketed where he was appointed as Minister of Foreign Affairs in 1997 and the secretarygeneral of ASEAN since 2006 becomes an evidence of the monumental achievement of Malay descent Muslims in Nakhon Si Thammarat. His successful political career consequently raised the pride for the Malay descent Muslim community in the province. It is in contrast to Pattani, which despite having a proportionately larger Muslim population than Nakhon Si Thammarat, only has one representative in the provincial council are not provided with access to electoral democracy since a representative is directly appointed by the central government.

By looking at the amalgamation of social and local political representation, it is apparent that the government has adopted two different approaches to deal with the Muslim in two different regions. In Nakhon Si Thammarat, the government uses soft power by opening various accesses for the Muslim community to ensure a normal life as any other Thai citizens. On the other hand, in Pattani the government shows a strong hand through the use of military controls and restricts the movement of the Muslim community. Yet, instead of stifling the insurgency in the region, the controls and restrictions only triggered social resistance, which results in further political instability.

The difference in policy approaches and the level of access disclosure further led to different economic growth in both provinces. The peaceful condition in Nakhon Si Thammarat allows the Muslim community to participate in the economy without any constrains. This is evidenced through the rapid growth of Muslim-owned businesses, especially in the culinary, hospitality, marine, automotive and property sectors (Interview with Arafat and Haji Shugur, Local businessman of Nakhon Si Thammarat, October 10, 2017). Under the prime ministership of Thaksin Shinawatra, the government increasingly opens economic access for the Muslim community and plays a major role in boosting their economic growth, particularly by facilitating the establishment of Islamic Bank of Thailand (I-Bank). Interestingly, it turns out that I-Bank customers are not only limited to the Muslim community, but it also provides services for the general public.

In addition to capital provision from I-Bank, Al-Muslimoon cooperative, 
which was established in 2001, also become an option for Muslims. AlMuslimoon initially only raised funds from the Muslim community in the township level, which then grew over time and began to embrace a larger number of members. The cooperative, which mainly operate in the rural area, also contributed to improving the Muslim community's welfare by serving Malay descent Muslims living below the poverty line.

The opening of access to the capital in Nakhon the Thammarat carries a positive impact marked by widening opportunities for job vacancies in the enterprise sector, the declining poverty rate, and the increasing income of the Muslim community. The access to capital greatly contributes towards the restructuring of Nakhon Si Thammarat Muslims in establishing economic balance and eliminating the justification of prosperity based on ethnicity and religion. It inevitably led to accelerated growth of a new Muslim middle class with the continuous growth of entrepreneurs. Despite their economic emergence, the Muslims in Nakhon SI Thammarat is faced with the fact that land in the province is mainly owned by Thai Chinese citizens. Therefore, it is impossible for the Muslim entrepreneurs to fight them through a frontal competition, instead they will have to adapt to an economic sharing to gain access to capital market for a greater profit. This means that to counter the Thai Chinese ethnic hegemony, the only possible way for Muslims is to position themselves as business partners instead of competitors, because otherwise the Muslims will certainly lose out of the financial and networking opportunities.

This is in contrast to Pattani, in which the grip of access restriction in various fields has slackened local economic growth. Instead of creating a sense of safety, the state, through their vigorous control as represented by the police and military pressure of surveillance in the city corners, has led to the feeling of insecurity. The only vibrant economic heartbeat is most visibly detected in the heart of Pattani City; in Charoenpradit Road with its boisterous economic activities. However, the further from the main road, there will be a sense of economic deprivation, especially after 9 PM local time when the atmosphere becomes increasingly tense. It is impossible for the local communities to conduct their activities outside the house since the 
curfew, where violations will only lead to military interrogation and arrest.

Amidst the situation, the government offered help by trying to open access through a skill training program called klummaeban, which is training aid as a part of One Thambon One Product (OTOP) program. The OTOP program aims to increase the output of micro, small and medium enterprises throughout Thailand. At first the Muslim community welcomed the training program, but gradually most of the people decided to leave it because klummaeban activities were often deemed incompatible with the culture of the Malay Thais. An example is the absence of praying time during training. The decision of the community to abandon the klummaeban program certainly affected their income. Yet, despite their loss of income from the government they still prefer to stop participating in the program. Those who stopped participating prefers to seek other sources of income rather than exchanging their religious principles with government rules. However, it appears that lack of capital and lack of skills make it difficult for them to benefit from other sources of income.

Despite having more options in terms of access to capital than Muslims in
Nakhon Si Thammarat, the Pattani Muslim community still falters economically. If in Nakhon Si Thammarat the Muslim community relies solely on I-Bank and Al-Muslimoon Cooperative, in Pattani besides I-Bank there are two cooperatives that are bigger in terms of membership than Al-Muslimoon, which are the Ibnu Affan and Pattani Muslim Cooperative. While both Ibnu Affan and Pattani Muslim Cooperative are well received by the Muslims who keenly come to seek capital, unfortunately, there are various obstacles hindering the growth of the two cooperatives. Some of them are the lack of knowledge or social understanding and unclear legal basis for Islamic cooperative establishment. Moreover, Pattani Muslims are also reluctant to access capital from I-Bank as they see the I-Bank as a representation of the central government. In other words, Nakhon Si Thammarat Muslims are more accustomed to using modern financial systems, which inevitably engenders better economic conditions for them, and on the other hand the Muslims in Pattani are not as well accustomed in using modern banking financial system, which slackens their economic growth.

As seen from the class formation, Muslims in Nakhon Si Thammarat 
are pretty apt at aligning themselves socially with other ethnicities. However, economically they are still incomparable with the Thai Chinese citizens in terms of the amount of deposit in the I- Bank. The rise of Muslim life is primarily influenced by the supportive government policies that provide them with access and facilities towards education and capital, which is welcomed by the entrepreneurial spirit of Muslims in Nakhon Si Thammarat. Thus, it is possible to assume that the growth of the Muslim middle class in Nakhon Si Thammarat is underpinned by the meeting between state driven and market driven factors in a productive spirit. In contrast, the middle-class citizens in Pattani predominantly are Thai Chinese, while the Muslim Malay middle class is left with little room to thrive. This is principally engendered by government policies that restrict access for Muslims and are aggravated by the Pattani Muslims' withdrawal from viable economic opportunities themselves, which is evidenced by their reluctance to access the capital from institutions using modern banking systems and their exit from the klummaeban programs.

Differences in the condition between the Muslim community in
Nakhon Si Thammarat and Pattani as explained above resulted in a direct impact on the level of welfare and growth of their middle class. The next question to answer is how the diverse Muslim middle-class trajectory is expressed in the public sphere. So far, the level of prosperity is closely related to one's lifestyle and this is also true in Thailand. The Thai middle class is closely associated with their high incomes and consumptive culture, and they desire to express their religious identity in the public sphere. It appears that in Nakhon Si Thammarat, the Muslim middle class is thriving because they are supported by wide access that spurs the acceleration of economic growth. However, the Muslim middleclass in this province do not necessarily use up their income for pleasure or lifestyle. They also do not crave to display their Islamic identity in the public sphere. They prefer to use their income or business profits to raise and expand their businesses. In fact, some of their income is allocated to help other fellow Muslim businesses. In early 2017, several Muslim businessmen initiated the establishment of Nakhon Si Thammarat Muslim Business Club (NMBC) to bridge and unite Muslim businesses ranging from small scale to 
large scale in an association in order to strengthen the businesses.

The situation in Nakhin Si Thammarat is quite the reverse with Muslims Pattani. Despite the economic hardship they suffer from, the Muslims in Pattani are always craving for excessive Islamic identity and prosperity. Wearing Islamic clothes makes them feel elated as they feel a sense of pride as Malay Muslims as well as self-confidence as a Muslim who keeps up with the latest trend or contemporary fashion. In Pattani, it is deemed important to display religious expression in everyday life. It is primarily because the Pattani Muslim would like others to get an impression that they are wealthy through their outfits, despite the fact that they are economically impoverished. It is as if the only way to express their resistance against the government no matter how hard the repressive measures, no matter how restricted their access towards many things are, Muslims in Pattani will remain strong and fight back. It is essential for them to maintain their dignity as Malay Muslims. In other words, to put it in brief, in Pattani, religious expression is visible through the way the people dress in luxury, which sets as a symbol of resistance in the public sphere.

\section{Conclusion}

Taking heed on Indonesia, the state once enacted a policy in favor of the growth of the Muslim middle class through the Benteng economic program. However, it turned out that the program failed. During president Soeharto's New Order period, the state developed a pattern of capitalism that further encouraged the middle-class growth in the president's crony circle, be it among the bureaucracy, technocrats, bureaucracy, politicians and their own kin. However, it turned out that the New Order regime has failed to embrace the Muslim communal power while the urban Muslims continued to blossom and boom in the process of Muslim market reinforcement. As seen from the context of the political reform, it is clear that electoral democracy and regional autonomy policies have supported the growth of the Muslim middle class in many cities. Some people have managed to come to the fore by running for public office positions in the government through the political opening afforded by electoral democracy. Meanwhile, others may find themselves independently struggleing for success by seizing opportunities in the Muslim market through the monetization of Islamic lifestyle. 
In Malaysia, the government issued NEP as the first wave policy revolution with the primary aim to strengthen the national capital of the Malay bumiputra who are identical to Muslims. To strengthen the bumiputras' access in state industry, the government established the Industrial Co-ordination Act and the BCIC. Aside of these policies, the government also aided the improvement of the Malays' human resources by establishing new higher education institutions and assigning a certain quota for them. Another affirmative policy for the Malays is the ease in accessing jobs, housing and land in the country's new industrial land areas. The second wave of policy revolution moves from focusing on ethnic-based affirmative policies to the NEP in the 1990s, which lessens the bumiputra's privileges but supports privatization. In this stage, the focus on infrastructure development and affirmative policy towards privatization diversifies the Malay Muslim's profession, who are at this point already benefited from the affirmative policy on the first policy revolution. The rise of the Muslim middle class in Malaysia was driven by the state as is indicated by the first and second policy revolutions. The rapid growth of the Malay Muslim middle class is attributed to several interconnected factors namely the ethnicity-based policies, the intellectual mobility and the global market. The religious expression of the Muslim middle class in public sphere can be see through the state's sharia policies, the consumption of Islamic goods, and Islamic philanthropy.

The Muslim middle class in Southern Thailand has been hindered to grow independently despite market forces and opportunities offered by digital economic advancements. As the military took control over civilian politics in the region, the situation exacerbated the already prickly political condition of Muslims in the insurgency-ridden provinces, such as in Pattani, Yala and Narathiwat. The Muslim in these provinces suffers from the government's "hard power" policies and militaristic approach instead of seeing welfare-based policy approaches. Under the military political pressure, it is hard for the Muslims to prosper economically in these three predominantly Muslim provinces. The tight political control, which inevitably limits economic opportunities, hinders economic prosperity and the rise of the Muslim middle class. In contrast to the 
Muslim community in Pattani, in the case of Muslims in Nakhon Si Thammarat Province, the soft political power that the central government applied has provided Muslims with wider access to education, banking, employment and other economic opportunities which accordingly assures a conducive atmosphere for the growth of its Muslim middle class.

The development paradigm and political policy of a country greatly shaped the dynamics of the Muslim middle-class development in Indonesia, Malaysia and Thailand. While both the Indonesian and Malaysian government resorted to affirmative policy towards the Muslims, which allowed the Muslim middle class to prosper, in Thailand the government took a more diversified approach as a response to local Muslim community insurgency. As a result of a more diversified policy, different regions in Thailand saw different levels of prosperity amongst their Muslim communities. The different patterns in governmental approach towards development policies in these three Southeast Asian countries results in a variation of Muslim middle-class growth trajectories and their eventual Islamic expressions in the public sphere.

\section{Acknowledgement}

This research was funded by the Center for Research and Community Engagement (LP2M) Sunan Kalijaga State Islamic University through an international superior research scheme. The authors would like to thank Faculty of Human Ecology (FEM) Universiti Putra Malaysia; Islamic Studies and Muslim Society for Peaceful Social Integration Project (ISWU) Walailak University Thailand; and the Center for Southeast Asian Studies (CSEAS) Kyoto University Japan for all the support during the research and dissemination process.

\section{References}

Afzal, S. (2018). The middle class and ethnic identities in Malaysia: Transcending the paradox of Malaysian-ness. (Master's Thesis). Leiden University, Leiden, Netherlands.

Ali, H. \& Purwandi, L. (2017). Indonesian Muslim middle class: Religious and consumerism. Jakarta, Indonesia: Alvara Research Center.

Ariff, M. (2017). Islamic banking in Malaysia: The changing landscape. Institution and Economies, 9(2), 1-13.

Bagguley, P. (1992). Social Change, the middle class and the emergence of 
"new social movements": A critical analysis. The Sociological Review, 40(1), 26-48.

Balasubramaniam, V. (2007). A divided nation: Malay political dominance, Bumiputera material advancement and national identity in Malaysia. National Identities, 9(1), 35-48.

Borsuk, R. R. \& Chng, N. (2016). Liem Sioe Liong dan Salim grup: Pilar bisnis Soeharto. Jakarta, Indonesia: Kompas.

Fealy, G. (2008). Consuming Islam: Commodified religion and aspirational pietism in contemporary Indonesia. In G. Fealy and S. White (Eds.), Expressing Islam: Religious life and politics in Indonesia (pp. 15-39). Singapore: Institute of Southeast Asian Studies.

Fealy, G. \& White, S. (2008). Expressing Islam: Religious life and politics in Indonesia. Singapore: Institute of Southeast Asian Studies.

Fischer, J. (2008). Proper Islamic consumption: Shopping among the Malay in modern Malaysia. Copenhagen, Denmark: Nias Press. Government of Malaysia. (1971). Second Malaysia Plan 1971-1976. Retrieved from www.epu.gov.my/sites/default/ files/rmk2_bm_chapter_01.pdf
Guan, L. H. (2002). Malay dominance and opposition politics in Malaysia. Singapore: ISEAS - Yusof Ishak Institute.

Hansen, N. et al. (1990). Regional policy in changing world. New York, NY: Plenum Press.

Hasan, S. S. S. (2000). Islamization and urban religious identity: The middle class of Bandar Baru Bangi. Paper presented at the International Seminar and Workshop on Beyond the Crisis: Southeast Asian Middle Classes in $21^{\text {st }}$ Century. Kuala Lumpur, Malaysia. Hefner, R. W. (1995). ICMI dan perjuangan menuju kelas menengah Indonesia. Yogyakarta, Indonesia: Tiara Wacana.

Hisyam, M. (2006). Budaya kewargaan komunitas Islam di daerah aman dan rentan konflik. Jakarta, Indonesia: LIPI. Islam, S. S. (1998). The Islamic independence movements in Patani of Thailand and Mindanao of the Philippines. Asian Survey 38 (5), 441-456.

Jati, W. R. (2017). Politik kelas menengah Muslim Indonesia. Jakarta, Indonesia: LP3ES.

Jones, C. (2007). Fashion and faith in urban Indonesia. Fashion Theory, 11(2/3), 211-232. 
Jurdi, S. (2013). Gerakan sosial Islam: Kemunculan, eskalasi, pembentukan blok politik dan tipologi artikulasi gerakan. Jurnal Politik Profetik, 1(1), 1-24.

Lall, S. (1995). Malaysia: Industrial success and the role of the government. Journal of International Development, 7(5), 759-773.

Laucereno, S. F. (2017, October 23). Wawancara lengkap Yusuf Mansur soal PayTren dan mimpi membeli Indonesia. Detik Finance. Retrieved from www.finance. detik.com/wawancara/3696722/ wawancara-lengkap-yusuf-mansursoal-paytren-dan-mimpi-membeliindonesia

Masitho, B. (2013). Dinamika politik pembangunan pada masa Orde Baru. Jurnal Perspektif, 6(2), 118123.

Nagaraj S. et al. (2015). Counting ethnicity in Malaysia: The complexity of measuring diversity. In Simon, P. et al. (eds). Social statistics and ethnic eiversity (pp. 143-173). IMISCOE Research Series. Springer, Cham.

Neo, J, L. (2006). Malay nationalism, Islamic supremacy and the constitutional bargain in the multiethnic composition of Malaysia.
International Journal on Minority and Group Rights, 13(1), 95-118.

Mohammad, M. (1991). Malaysia: The Way Forward (Vision 2020). Kuala Lumpur, Malaysia: Percetakan Nasional Malaysia Berhad.

Robison, R. (2012). Soeharto dan bangkitnya kapitalisme Indonesia. Jakarta, Indonesia: Komunitas Bambu. Robison, R. \& Goodman, D.S.G. (2013). Rich in Asia: Mobile phones, McDonald's and middle class revolution. London, United Kingdom: Routledge.

Romli, L. (2004). Partai Islam dan pemilih Islam di Indonesia. Jurnal Penelitian Politik, I(1), 29-48.

Schønemann, J. (2013). The stereotyping of Muslims: An analysis of The New York Times' and The Washington Times' coverage of veiling and the Muhammad Cartoon Controversy (Master's Thesis). University of Oslo, Oslo, Norway.

Talib, R. (2000). Malaysia: Power shift and the matrix of consumption. In Beng-Huat, C. (Ed.), Consumption in Asia: Lifestyle and identity (pp. 35-61). London, United Kingdom: Routledge.

The Jakarta Post. (2013, September 25). Prospects for cosmetics 
industry are looking Good. The Jakarta Post. Retrieved from https://www.thejakartapost.com/ news/2013/09/25/prospectscosmetics-industry-are-lookinggood.html

Thillainathan, R. \& Cheong, K.C. (2015). Malaysia's new economic policy, growth and distribution: Revisiting the debate. Malaysian Journal of Economic Studies, 53(1), 51-68.

Wiharja, M. M. \& Negara, S. D. (2015). The Indonesian economy from the Colonial Extraction period until the Post-New Order period: A review of Thee Kian Wie's Major Works. Economics and Finance in Indonesia 61(1), 41-52.

Wright, E. O. (1989). The comparative project on class structure and class consciousness: A review. Acta Sociologica 32(1), 3-22.

Yacoob, Y. \& Azmi, I. A. G. (2012). Entrepreneurs' personality from Islamic perspective: A study of successful Muslim entrepreneurs in Malaysia. International Proceedings of Economics Development and Research, 46, 86-90. 